\title{
Peptides: Molecular and Biotechnological Aspects
}

\author{
Hamilton Cabral
}

check for updates

Citation: Cabral, H. Peptides: Molecular and Biotechnological Aspects. Biomolecules 2021, 11, 52. https://doi.org/10.3390/biom11010052

Received: 19 December 2020 Accepted: 22 December 2020 Published: 1 January 2021

Publisher's Note: MDPI stays neutral with regard to jurisdictional clai$\mathrm{ms}$ in published maps and institutional affiliations.

Copyright: $\odot 2021$ by the author. Licensee MDPI, Basel, Switzerland. This article is an open access article distributed under the terms and conditions of the Creative Commons Attribution (CC BY) license (https:// creativecommons.org/licenses/by/ $4.0 /)$.
Department of Pharmaceutical Sciences, School of Pharmaceutical Sciences of Ribeirão Preto, University of São Paulo, Ribeirão Preto, SP 14040-903, Brazil; hamilton@fcfrp.usp.br; Tel.: +55-16-3315-4970

Since the isolation and commercialization of insulin (a peptide composed of 51 amino acid residues) in the early 1920s, peptide drugs have reshaped the pharmaceutical industry [1], and their utilization continues to increase in medicine, biotechnology, and therapeutic research [2].

In 1950, Mellander was the first researcher to report bioactive peptides, suggesting that a set of casein-derived phosphopeptides increased vitamin D-dependent bone calcification in infants [3].

Bioactive peptides are amino acid sequences, ranging from 2 to 20 residues, that are hidden and inactive in proteins present in food [4]. These protein fragments present biological activity when released from the molecule of origin via hydrolysis by peptidases of the digestive system [5].

Bioactive peptides can be obtained through the action of peptidases secreted by microorganisms during the fermentation process in the presence of proteins; through hydrolysis using vegetal, animal, and microorganism peptidases; and through the gastrointestinal enzymatic processes [6]. Hydrolysis with peptidases is the most common method for the generation of bioactive peptides [6], whereby proteolytic enzymes, commonly called peptidases, catalyze the hydrolysis of peptide bonds. Each of these enzymes demonstrates a specificity towards each bioactive peptide [7].

Protein sources for peptide production are selected based on value-added proteins and amino acid sequences of pharmacological interest [8]. Thus, animal and vegetal enzymes are commonly used to obtain bioactive peptides [9], with most studies using milk, egg, meat, and fish proteins. The most common vegetal protein sources used in bioactive peptide production include soy, lentils, chickpeas, peas, beans, oats, and wheat [8]. Generally, peptides released by food protein hydrolysis present fewer side effects [10].

Bioactive peptides can present myriad biofunctionalities, depending on several characteristics, including amino acid sequences (extension, hydrophobicity, and load), and can also present multifunctionalities, thereby acting in different systems $[4,11]$. They modulate biological functions by interacting with specific target cell receptors, thereby triggering a beneficial physiological response in the body [12].

Several bioactive peptides obtained from various food sources, presenting multiple biological activities, have been reported in the literature [13]. Some of the activities have been reported in hypocholesterolemia [14] and dipeptidyl peptidase IV inhibition [15], along with antithrombotic, antioxidant [16], antihypertensive [17], antimicrobial [18], immunomodulatory [19], cytomodulatory [20], and antitumor [21] activities.

The use of omics techniques, including metabolomics, proteomics, and genomics, for analysis of toxins and other peptide sources can help identify bioactive peptides with unique structural characteristics generated by post-translational modifications [22]. Additionally, the development of bioinformatics and peptide databases is considered a precious strategy that can predict the action/function of these small molecules in organisms [23].

The safety of nano-encapsulated bioactive peptides should be carefully considered for toxicity related to increased functions and possible allergic reactions. To develop a safety evaluation strategy for bioactive proteins, other techniques can be used in addition to toxin 
and allergen examination, thereby increasing the efficiency of bioactive peptide evaluations in the future; analysis of the history of the protein source used, establishment of the structure-activity relationship of peptides using bioinformatics resources, and development of sensitive detection techniques for toxins and potential allergens that may coexist in peptide products [24] can be realized via advancements in techniques for such purposes.

The use of peptides in therapy has improved over time and will continue to advance drug development and treatment strategies, thereby setting new paradigms. Improvements in peptide screening and computational biology will continue to support the discovery of peptide drugs [22]. The potential of peptide drugs is enormous and, therefore, with recent advances in peptide science, the oncoming era may be called "The Age of Peptides" [25].

Funding: This research was funded by Fundação de Amparo à Pesquisa do Estado de São PauloFAPESP, grant number 2016-20385-2.

Acknowledgments: I would like to thank all the authors for their valuable contributions.

Conflicts of Interest: The author declares no conflict of interest.

\section{References}

1. Lee, A.C.L.; Harris, J.L.; Khanna, K.K.; Hong, J.H. A Comprehensive Review on Current Advances in Peptide Drug Development and Design. Int. J. Mol. Sci. 2019, 20, 2383. [CrossRef] [PubMed]

2. Erdmann, K.; Cheung, B.W.Y.; Schröder, H. The possible roles of food-derived bioactive peptides in reducing the risk of cardiovascular disease. J. Nutr. Biochem. 2008, 19, 643-654. [CrossRef] [PubMed]

3. Korhonen, H.; Pihlanto, A. Food-derived Bioactive Peptides - Opportunities for Designing Future Foods. Curr. Pharm. Des. 2003, 1297-1308. [CrossRef]

4. Martínez-Medina, G.A.; Barragán, A.P.; Ruiz, H.A.; Ilyina, A.; Hernández, J.L.M.; Rodríguez-Jasso, R.M.; Hoyos-Concha, J.L.; Aguilar-González, C.N. Fungal Proteases and Production of Bioactive Peptides for the Food Industry. In Enzymes in Food Biotechnology, 1nd, ed.; Mohammed Kuddus; Elsevier Academic Press: San Diego, CA, USA, 2019; pp. 1-909.

5. Mohanty, D.P.; Mohapatra, S.; Misra, S.; Sahu, P.S. Milk derived bioactive peptides and their impact on human health-A review. Saudi J. Biol. Sci. 2015, 23, 577-583. [CrossRef]

6. Sultan, S.; Huma, N.; Butt, M.S.; Aleem, M.; Abbas, M. Therapeutic potential of dairy bioactive peptides: A contemporary perspective. Crit. Rev. Food Sci. Nutr. 2017, 58, 105-115. [CrossRef]

7. Hamin-Neto, Y.A.A.; Rosa-Garzon, N.G.; Pedezzi, R.; Cabral, H. Specificity of peptidases secreted by filamentous fungi. Bioengineered 2017, 9, 30-37. [CrossRef]

8. Udenigwe, C.C.; Aluko, R.E. Food protein-derived bioactive peptides: Production, processing, and potential health benefits. J. Food Sci. 2012, 77, R11-R24. [CrossRef]

9. Bhat, Z.F.; Kumar, S.; Bhat, H.F. Bioactive peptides of animal origin: A review. J. Food Sci. Technol. 2015, 52, 5377-5392. [CrossRef]

10. Li-Chan, E.C.; Euniceli-Chan, E.C. Bioactive peptides and protein hydrolysates: Research trends and challenges for application as nutraceuticals and functional food ingredients. Curr. Opin. Food Sci. 2015, 1, 28-37. [CrossRef]

11. Lemes, A.C.; Sala, L.; Ores, J.C.; Braga, A.R.C.; Egea, M.B.; Fernandes, K.F. A review of the latest advances in encrypted bioactive peptides from protein-rich waste. Int. J. Mol. Sci. 2016, 17, 950. [CrossRef] [PubMed]

12. Fitzgerald, R.J.; Murray, B.A. Bioactive peptides and lactic fermentations. Int. J. Dairy Technol. 2006, 59, 118-125. [CrossRef]

13. Chalamaiah, M.; Ulug, S.K.; Hong, H.; Wu, J. Regulatory requirements of bioactive peptides (protein hydrolysates) from food proteins. J. Funct. Foods. 2019, 58, 123-129. [CrossRef]

14. Marques, M.R.; Fontari, G.G.; Pimenta, D.C.; Soares-Freitas, R.M.; Arêas, J.A.G. Proteolytic hydrolysis of cowpea proteins is able to release peptides with hypocholesterolemic activity. Food Res. Inter. 2015, 77, 43-48. [CrossRef]

15. Fontoura, R.; Dariot, D.J.; Correa, A.P.F.; Meira, S.M.M.; Mosquera, M.; Brandelli, A. Production of feather hydrolysates with antioxidant, angiotensin-I converting enzyme- and dipeptidyl peptidase-IV-inhibitory activities. N. Biotechnol. 2014, 31, 506-513. [CrossRef] [PubMed]

16. Zheng, L.; Zhao, M.; Xiao, C.; Zhao, Q.; Su, G. Practical problems when using ABTS assay to assess the radical-scavenging activity of peptides: Importance of controlling reaction $\mathrm{pH}$ and time. Food Chem. 2016, 192, 288-294. [CrossRef] [PubMed]

17. Cian, R.E.; Vioque, J.; Drago, S.R. Structure-mechanism relationship of antioxidant and ACE-I inhibitory peptides from wheat gluten hydrolysate fractionated by pH. Food Res. Int. 2015, 69, 216-223. [CrossRef]

18. Rahmawati, I.S.; Suntornsuk, W. Effects of fermentation and storage on bioactive activities in milks and yoghurts. Procedia Chem. 2016, 18, 53-62. [CrossRef]

19. Bonomi, F.; Brandt, R.; Favalli, S.; Ferranti, P.; Fierro, O.; Frokiaer, H.; Ragg, E.; Iametti, S. Structural determinants of the immunomodulatory properties of the C-terminal region of bovine $\beta$-casein. Int. Dairy J. 2011, 21, 770-776. [CrossRef] 
20. Plaisancié, P.; Claustre, J.; Estienne, M.; Henry, G.; Boutrou, R.; Paquett, A.; Léonil, J. A novel bioactive peptide from yoghurts modulates expression of the gel-forming MUC2 mucin as well as population of goblet cells and Paneth cells along the small intestine. J. Nutr. Biochem. 2013, 24, 213-221. [CrossRef]

21. Oh, G.W.; Ko, S.C.; Heo, S.Y.; Nguyen, V.T.; Kim, G.H.; Jang, H.C.; Park, W.S.; Choi, I.W.; Qian, Z.J.; Jung, W.K. A novel peptide purified from the fermented microalga Pavlova lutheri attenuates oxidative stress and melanogenesis in B16F10 melanoma cells. Process Biochem. 2015, 50, 1318-1326. [CrossRef]

22. Lau, J.L.; Dunn, M.K. Therapeutic peptides: Historical perspectives, current development trends, and future directions. Bioorg. Med. Chem. 2018, 26, 2700-2707. [CrossRef] [PubMed]

23. Bechaux, J.; Gatellier, P.; Le Page, J.F.; Drillet, Y.; Sante-Lhoutellier, V. A comprehensive review of bioactive peptides obtained from animal byproducts and their applications. Food Funct. 2019, 10, 6244-6266. [CrossRef] [PubMed]

24. Zhao, C.; Ashaolu, T.J. Bioactivity and safety of whey peptides. Food Sci. Technol. 2020, 134, 109935. [CrossRef]

25. Sachdeva, S. Peptides as 'Drugs': The Journey so Far. Int J Pept Res Ther. 2017, 23, 49-60. [CrossRef] 